\title{
Trwałość spawanych instalacji wodnych wykonanych z nierdzewnych stali austenitycznych
}

\author{
Durability of welded water supply pipelines \\ made of austenitic stainless steels
}

\begin{abstract}
Streszczenie
W artykule przedstawiono dwa przypadki przedwczesnych uszkodzeń spawanych instalacji wodnych wykonanych ze stali odpornej na korozję. W celu ustalenia przyczyn uszkodzenia instalacji przeprowadzono badania metalograficzne makro- i mikroskopowe oraz mikroanalizę składu chemicznego EDS na próbkach pobranych z reprezentatywnych miejsc. Wykazano, że głównymi przyczynami awarii rurociągów wody pitnej były niezgodności spawalnicze, które przyczyniły się do korozyjnego uszkodzenia instalacji. $\mathrm{Na}$ podstawie uzyskanych wyników sformułowano wnioski dotyczące przyczyn uszkodzenia odcinków rurociągów oraz zalecenia dotyczące trwałości spawanych instalacji wodociągowych ze stali nierdzewnych austenitycznych.
\end{abstract}

Słowa kluczowe: AISI 304; stal austenityczna; uszkodzenie; korozja; rurociągi

\begin{abstract}
Two cases of premature failure of welded water supply pipelines made of stainless steel are presented in this article. Metallographic examinations and EDX microanalysis of the corrosion products on selected samples has been carried out to determine causes responsible for failures. Examinations revealed that main causes of welded water supply pipelines failure were welding imperfections which lead to the corrosion damage. On the basis of received results conclusions about causes of pipelines damages and recommendations for durability of welded water supply pipelines made of austenitic stainless steels were formed.
\end{abstract}

Keywords: AISI 304; austenitic stainless steel; failure; corrosion; pipelines

\section{Wstęp}

Powszechnie stosowanymi na instalacje wodne materiałami metalowymi są: miedź i stopy miedzi (brązy, mosiądze), stal ocynkowana oraz stale odporne na korozję. Obecnie jako materiał instalacji do przesyłania wody pitnej oraz ciepłej wody użytkowej coraz częściej wykorzystywane są austenityczne stale nierdzewne, które ze względu na wysoką odporność korozyjną, gwarantują długotrwałą bezawaryjną pracę, ale również spełniają wymagania sanitarne norm i przepisów dotyczące np. rozwoju bakterii oraz rozpuszczania materiału instalacji i wzbogacania wody w jony metalu $[1 \div 3]$. Z tych powodów $\mathrm{m}$. in. odchodzi się od stosowania rur ze stali ocynkowanej, które są mniej odporne na korozyjne działanie wody wodociągowej i mają ograniczenie stosowania w kontakcie z ciepłą wodą do $55^{\circ} \mathrm{C}$. Aktualne wymagania trwałości instalacji wodnej min. 50 lat i wymagania utrzymania ciepłej wody w granicach $55 \div 60{ }^{\circ} \mathrm{C}$ promują zastosowanie na instalacje wodne stali austenitycznych $[1,2]$.

Stale austenityczne są w stanie spełnić wszystkie wymagania stawiane materiałom na instalacje wodne pod warunkiem zapewnienia prawidłowego procesu montażu, a zwłaszcza spawania oraz kontroli podczas eksploatacji. Nieprawidłowości $w$ procesie wykonywania złączy ze stali austenitycznych często są główną przyczyną procesów korozyjnych instalacji pomimo tego, że woda wodociągowa wydaje się być bardzo łagodnym środowiskiem korozyjnym $[2,4 \div 7]$.

W systemach rozprowadzania i magazynowania wody stale austenityczne z uwagi na stan pasywny nie są zagrożone korozją galwaniczną. Korozja równomierna też nie stanowi problemu ze względu na bardzo małą szybkość procesu. Natomiast korozja lokalna: wżerowa, szczelinowa, naprężeniowa, międzykrystaliczna i zmęczeniowa może wystąpić w warunkach miejscowego uszkodzenia warstewki pasywnej. Przyczyny wystąpienia korozji lokalnej są spowodowane wieloma czynnikami, które można rozpatrywać w grupach dotyczących: czynników materiałowych, parametrów wody, projektu i wykonawstwa instalacji, stanu przekazania instalacji do eksploatacji i próby ciśnieniowej oraz warunków eksploatacji instalacji $[2,5]$.

Dr hab. inż. Jerzy Łabanowski, mgr inż. Mateusz Jurkowski, dr inż. Dariusz Fydrych, dr inż. Grzegorz Rogalski - Politechnika Gdańska.

Autor korespondencyjny/Corresponding author. jlabanow@pg.gda.pl 


\section{Czynniki materiałowe}

Ryzyko wystąpienia korozji wżerowej i szczelinowej stali austenitycznych obniża się wraz ze wzrostem zawartości chromu, molibdenu i azotu w stali, jeśli pozostałe warunki pozostają stałe. Według wymagań PN-EN 10312 do wykonania rur kontaktujących się $z$ wodą pitną zalecane są stale zawierające molibden. Zawartość molibdenu w składzie chemicznym stali powyżej $2 \%$ zwiększa trwałość warstwy pasywnej a przez to umożliwia stosowanie tego typu stali w środowiskach o zwiększonej zawartości jonów chlorkowych. Stan powierzchni stali nierdzewnej ma duży wpływ na jej odporność korozyjną. Tylko czysta i wolna od wszelkich zanieczyszczeń organicznych i metalicznych powierzchnia stali zapewnia największą odporność na korozję. Należy szczególnie unikać kontaktu z cząstkami stali niestopowych lub niskostopowych, które mogą zostać osadzone lub wbite do warstwy wierzchniej stali nierdzewnej. Dzieje się tak często podczas wspólnego składowania stali nierdzewnej i węglowej, podczas obróbki mechanicznej obu rodzajów stali tymi samymi narzędziami, a zwłaszcza podczas szlifowania stali węglowych w sąsiedztwie stali nierdzewnych. Produkty korozji osadzonych cząstek stali węglowych zawierające jony $\mathrm{Fe}^{3+}$ są czynnikami silniej utleniającymi niż rozpuszczony w wodzie tlen $[2,3,5,8]$.

W przypadku korozji naprężeniowej zagrożenie uszkodzeniem zmniejsza się wzrostem stężenia niklu w stali. Usunięcie naprężeń rozciągających w elementach kształtowanych plastycznie na zimno można osiągnąć poprzez obróbkę cieplną, wyżarzanie odprężające i przesycanie $[9,10]$. Natomiast obróbki powierzchniowe: śrutowanie i kulowanie zalecane są w celu wytworzenia naprężeń ściskających i przez to ograniczenie podatności do korozji naprężeniowej.

Wzrost podatności na korozję wżerową i międzykrystaliczną stali nierdzewnych może też być skutkiem nieprawidłowej obróbki cieplnej - przesycania lub procesu spawania. Cykl cieplny spawania powoduje nagrzewanie materiału rodzimego w strefie wpływu ciepła (SWC) do temperatury w zakresie $500 \div 800{ }^{\circ} \mathrm{C}$. W konsekwencji może wystąpić uczulenie stali polegające na wydzielaniu się na granicach ziaren austenitu węglików $\mathrm{M}_{23} \mathrm{C}_{6} \mathrm{z}$ jednoczesnym zubożeniem $\mathrm{w}$ chrom przyległych obszarów ziaren austenitu znacznie poniżej poziomu niezbędnego do pasywacji $[1,5,8]$.

\section{Parametry wody}

Zagrożenie korozją wżerową i szczelinową wzrasta ze wzrostem stężenia jonów chlorkowych w wodzie. W stalach austenitycznych nie zawierających molibdenu w zimnej wodzie wodociągowej udział chlorków nie powinien przekraczać $6 \mathrm{mmol} / \mathrm{l}$, a w przypadku gorącej wody granica stężenia chlorków obniża się do poziomu 1,5 mmol/l. Zagrożenie korozją szczelinową stali bez molibdenu jest jeszcze większe, tzn. stężenie chlorków w całym roztworze powinno być znacznie niższe od $6 \mathrm{mmol} / \mathrm{l}$ w zimnej wodzie, a w ciepłej, na odsłoniętych powierzchniach stali, niższe od 1,5 mmol/l. Przy podanym granicznym stężeniu chlorków w wodzie zagrożenie korozją szczelinową występuje w niższej temperaturze niż w przypadku korozji wżerowej $[1 \div 2,4 \div 7]$.

\section{Wpływ projektu i wykonawstwa}

Wady i niezgodności powstałe $\mathrm{w}$ procesie spawania takie jak porowatość, podtopienia, brak przetopu, pozostałości żużli, rozpryski metalu zwiększają zagrożenie korozją wżerową i szczelinową. Podobnie oddziałują tworzące się podczas spawania stali nierdzewnych przebarwienia w sąsiedztwie spoin. Barwy nalotowe to pogrubione warstewki tlenków, które w zależności od swojej grubości obserwowane są jako naloty o określonym zabarwieniu $[1 \div 2,8]$.
Są to warstwy tlenkowe o odmiennej budowie w stosunku do warstw pasywnych, w mniejszym stopniu zabezpieczające przed korozją. Gruba warstwa tlenków na powierzchni stali zubaża w chrom materiał znajdujący się bezpośrednio pod warstwą. Zawartość chromu może obniżyć się poniżej granicznej wartości 10,5\% przyczyniając się do zwiększenia podatności stali na korozję. Jeśli warstwy tlenkowe mają barwę ciemniejszą niż słomkowa, ryzyko korozji wżerowej wzrasta. Jednakże nawet warstwy tlenkowe barwy słomkowej mogą w pewnych warunkach zwiększać ryzyko korozji wżerowej, dla określonych gatunków stali, składu wody i temperatury. Zabezpieczenie się przed tworzeniem przebarwień jest możliwe w warunkach spawania w skutecznej osłonie gazów obojętnych. Wszelkie barwy nalotowe, które powstaną na powierzchni stali po spawaniu powinny zostać usunięte. Należy przeprowadzić czyszczenie chemiczne, przepłukanie rurociągu i repasywację powierzchni $[8,11 \div 13]$.

Szczególnie niebezpieczne z punktu widzenia rozwoju korozji szczelinowej są pory i braki przetopu w grani spoin obwodowych. Skłonność do uszkodzeń korozyjnych gwałtownie wzrasta, gdy szczeliny są węższe niż $0,5 \mathrm{~mm}$ i gdy rośnie ich głębokość. Podatność na korozję szczelinową rośnie również, gdy zastosowane polimerowe materiały uszczelniające zawierają jony chlorkowe i emitują je do środowiska. Zwiększone ryzyko korozji szczelinowej występuje w przypadku dopuszczenia do zastoju wody lub przepływu z bardzo małą prędkością. W takich warunkach na powierzchniach poziomych rurociągów mogą tworzyć się osady z zanieczyszczeń pozostawionych podczas prac instalacyjnych, bądź z cząstek naniesionych przez wodę z dalszych gałęzi instalacji, często wykonanych z odmiennych materiałów. W przypadku łączenia instalacji należy zastosować filtry mechaniczne, które skutecznie chronią przed przedostawaniem się zanieczyszczeń pomiędzy instalacjami [2].

Czynniki geometryczne mogą wpływać na występowanie korozji zmęczeniowej rurociągów. W systemach z ciepłą wodą mogą występować naprężenia cykliczne wskutek rozszerzania i kurczenia się stali, należy temu przeciwdziałać przez prawidłowy projekt i wykonawstwo. Podobne zalecenia dotyczą ograniczenia naprężeń rozciągających od obciążeń zewnętrznych rurociągu w celu uniknięcia korozji naprężeniowej stali austenitycznych $[2,14,15]$.

\section{Wpływ próby ciśnieniowej i przekazanie do eksploatacji}

W przypadku, gdy po wykonaniu próby ciśnieniowej i odwodnieniu pozostają w instalacji resztki wody, rośnie ryzyko korozji wżerowej, ponieważ woda odparowując zwiększa stężenie chlorków. Zatem gotowa instalacja, jeszcze przed jej eksploatacją, powinna pozostać w stanie suchym lub w stanie napełnionym wodą.

Istotne jest również usunięcie cząstek stałych, które mogły zostać wprowadzone do rur podczas prac instalacyjnych. Gruntowne przepłukanie instalacji, natychmiast po pierwszym napełnieniu, zmniejsza ryzyko wystąpienia korozji szczelinowej pod osadami $\mathrm{w}$ trakcie eksploatacji $[1,2,6,14]$.

\section{Wpływ warunków eksploatacji systemu}

Zagrożenie korozją wżerową rurociągów wzrasta wraz ze wzrostem temperatury, a obniża się ze wzrostem prędkości przepływu wody. Podobnie jest w przypadku korozji szczelinowej. Zagrożenie uszkodzeniem rośnie wraz z temperaturą oraz w warunkach zastoju wody [2].

W dalszej części artykułu opisano dwa przypadki uszkodzeń instalacji do przesyłu ciepłej wody użytkowej wykonane ze stali austenitycznych, których czas eksploatacji wyniósł zaledwie kilka miesięcy. Wskazano przyczyny przedwczesnego uszkodzenia rur. 


\section{Analiza uszkodzeń odcinków rurociągów}

Badaniom zostały poddane dwa fragmenty rurociągów wody pitnej wykonane ze stali nierdzewnej austenitycznej gatunku X5CrNi18-10 wg PN-EN 10088-2:2007, co odpowiada stali AISI 304 . Oba odcinki rurociągów uległy przedwczesnemu uszkodzeniu po kilku miesiącach eksploatacji. Przyczyną wycofania rurociągów z dalszej eksploatacji było wystąpienie przecieków spowodowanych perforacją ścianek rur na skutek korozji.

Autorzy nie uzyskali danych dotyczących jakości wody, która płynęła wewnątrz rurociągów. Jednak ze względu na to, że były to instalacje wody pitnej założono, że skład chemiczny oraz pH wody nie przekraczały limitów dozwolonych przez dyrektywę Rady 98/83/WE [4].

\section{Przypadek 1}

Uszkodzony fragment instalacji wodociągowej składał się z odcinka rury o średnicy $\varnothing 48 \mathrm{~mm}$ i grubości ścianki $3 \mathrm{~mm}$ połączonego spoiną obwodową ze zwężką stożkową i dalej z rurą o średnicy $ø 33 \mathrm{~mm}$. Na powierzchni zewnętrznej zwężki stożkowej widoczne jest uszkodzenie w postaci perforacji punktowej w odległości ok. $10 \mathrm{~mm}$ od lica spoiny (rys. 1).

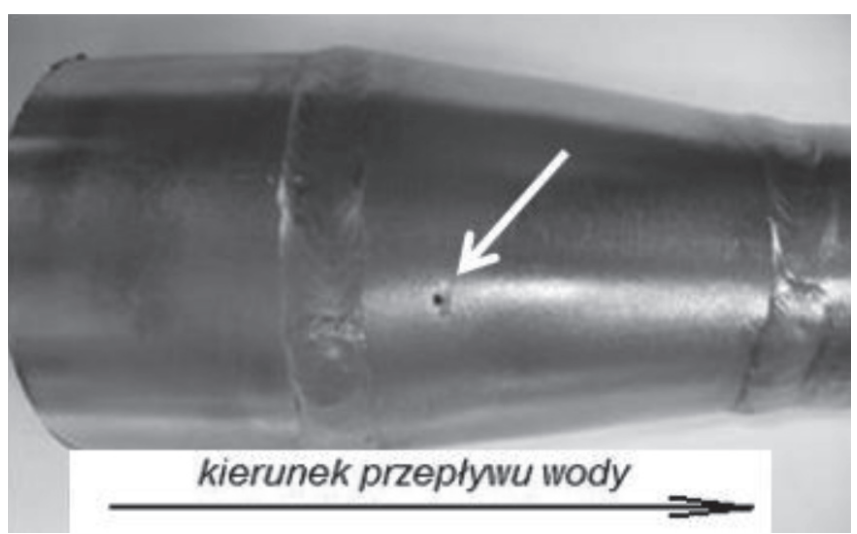

Rys. 1. Fragment uszkodzonego rurociągu z widoczną perforacją. Biała strzałka wskazuje perforację

Fig. 1. Part of the damaged pipeline with a visible perforation. The white arrow indicates the perforation

Po rozcięciu elementu stwierdzono, że cała powierzchnia wewnętrzna była pokryta cienkim osadem barwy słomkowej, a w kilku miejscach - ogniskach korozji - grubszym osadem barwy rdzawo-brunatnej. Perforacja wystąpiła wskutek rozwoju wżeru od powierzchni wewnętrznej w miejscu za spoiną, uwzględniając kierunku przepływu wody (rys. 2).

Mikroanaliza składu chemicznego (EDS) osadów występujących w obrębie ognisk korozyjnych wykazała obecność znacznych ilości żelaza i tlenu, ponadto cynk, wapń, miedź, ołów. Osady te powstały częściowo wskutek korozyjnego rozpuszczania stali, a częściowo zostały naniesione przez wodę zasilającą. Taka sytuacja często występuje podczas wstawiania odcinków instalacji ze stali austenitycznej $w$ istniejącą instalację wykonaną ze stali niestopowej ocynkowanej, z miedzi lub stopów miedzi. Położenie wżerów po jednej stronie grani spoiny nie było przypadkowe. Grań o wysokim nadlewie powodowała turbulencje w przepływie i skłonność do osadzania się stałych cząstek osadów oraz związków nieorganicznych przenoszonych z wodą. Pod warstwą osadzonych cząstek następuje miejscowy wzrost stężenia substancji szkodliwych, a zwłaszcza jonów $\mathrm{Cl}$, ponad dopuszczalny poziom, uszkodzenie warstewek pasywnych i inicjowanie wżerów korozyjnych.

Drugim ważnym czynnikiem sprzyjającym uszkodzeniom korozyjnym badanych rur było występowanie nieusu-

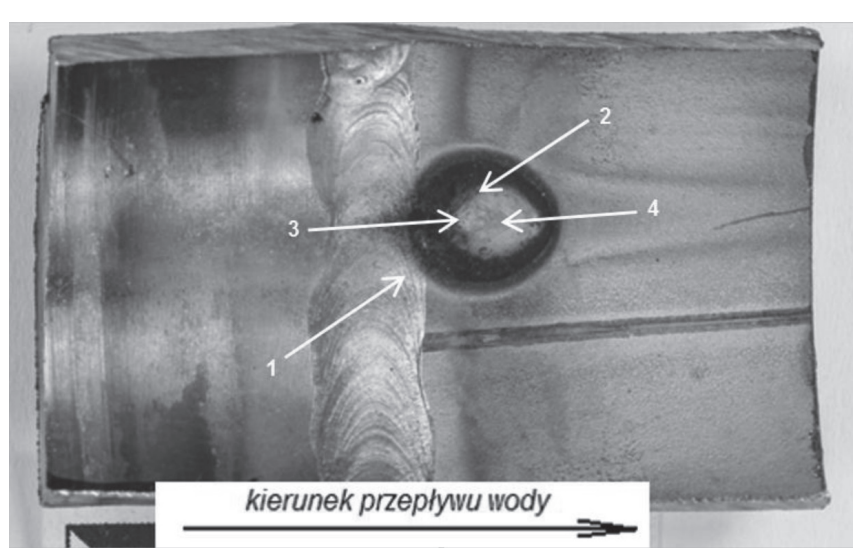

Rys. 2. Powierzchnia wewnętrzna uszkodzonego fragmentu rurociągu. Ognisko korozji przylegające do spoiny (1), obszar o barwie rdzawo-brunatnej (2), obszar o barwie zielonkawej (3), obszar o barwie słomkowej (4)

Fig. 2. Inner surface of damaged part of pipeline. Pitting corrosion initiation place adjacent to the weld root (1), reddish-brown area (2), greenish colour area (3), straw-coloured area (4)

niętych po procesie spawania charakterystycznych przebarwień po obu stronach grani spoiny (rys. 2). Obszary te stały się miejscem inicjacji korozji wżerowej rur. Przykład wżeru korozyjnego rozwijającego w głąb ściany rury w obszarze przebarwionym przy grani spoiny pokazano na rysunku 3a. Wżery miały kształt kawern z wąskim ujściem, co prowadzi do znacznego zakwaszenia roztworu wewnątrz wżeru i przyspiesza procesy anodowego rozpuszczania metalu. Na rysunku 3b przedstawiono fragment przekroju przez wżer korozyjny. Widać strukturę austenityczną rury i nieregularną (postrzępioną) powierzchnię wżeru świadczą o intensywnym przebiegu procesów korozyjnych.

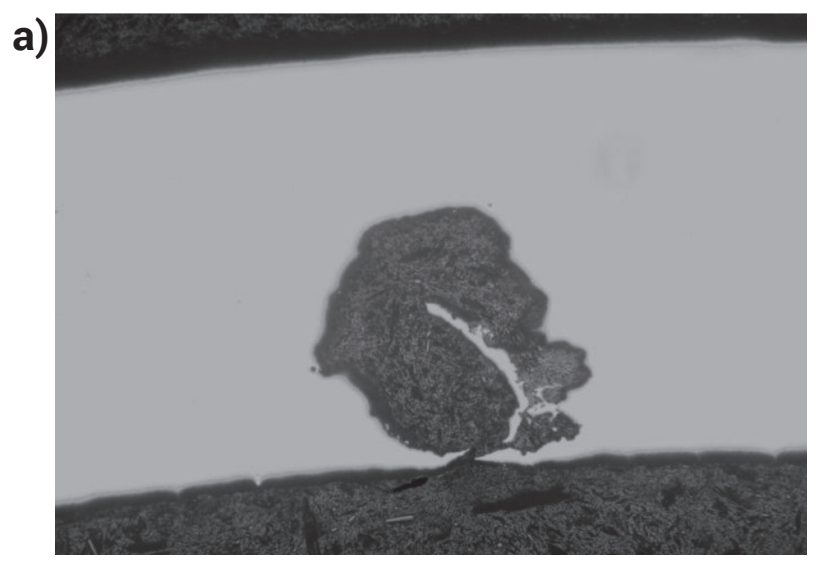

b)

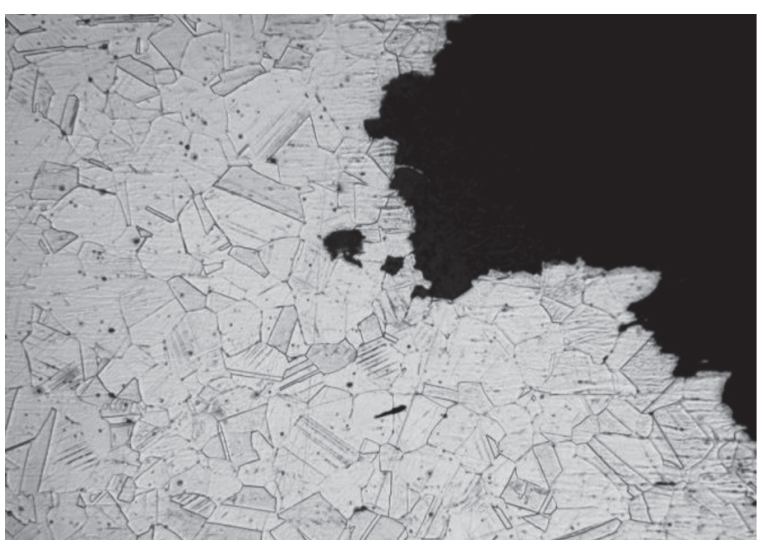

Rys. 3. Wżer korozyjny rozwijający się na głębokość równą połowie grubości ściany rury: a) zgład nietrawiony, pow. 20x; b) zgład trawiony $\mathrm{HNO}_{3}-\mathrm{HF}$, pow. $200 \mathrm{x}$

Fig. 3. Single corrosion pit near to the perforation. Unetched metallographic cross section, magnification $20 x$ 
Kolejne ognisko korozji występowało w grani spoiny, a jego źródłem były wtrącenia żużla osadzone w spoinie (rys. 4). Obecność wtrąceń cząstek żużla w grani spoiny jest niedopuszczalna i świadczy o niewłaściwym prowadzeniu procesu spawania (niewłaściwie oczyszczone powierzchnie elementów spawanych, silne utlenianie metalu podczas spawania).
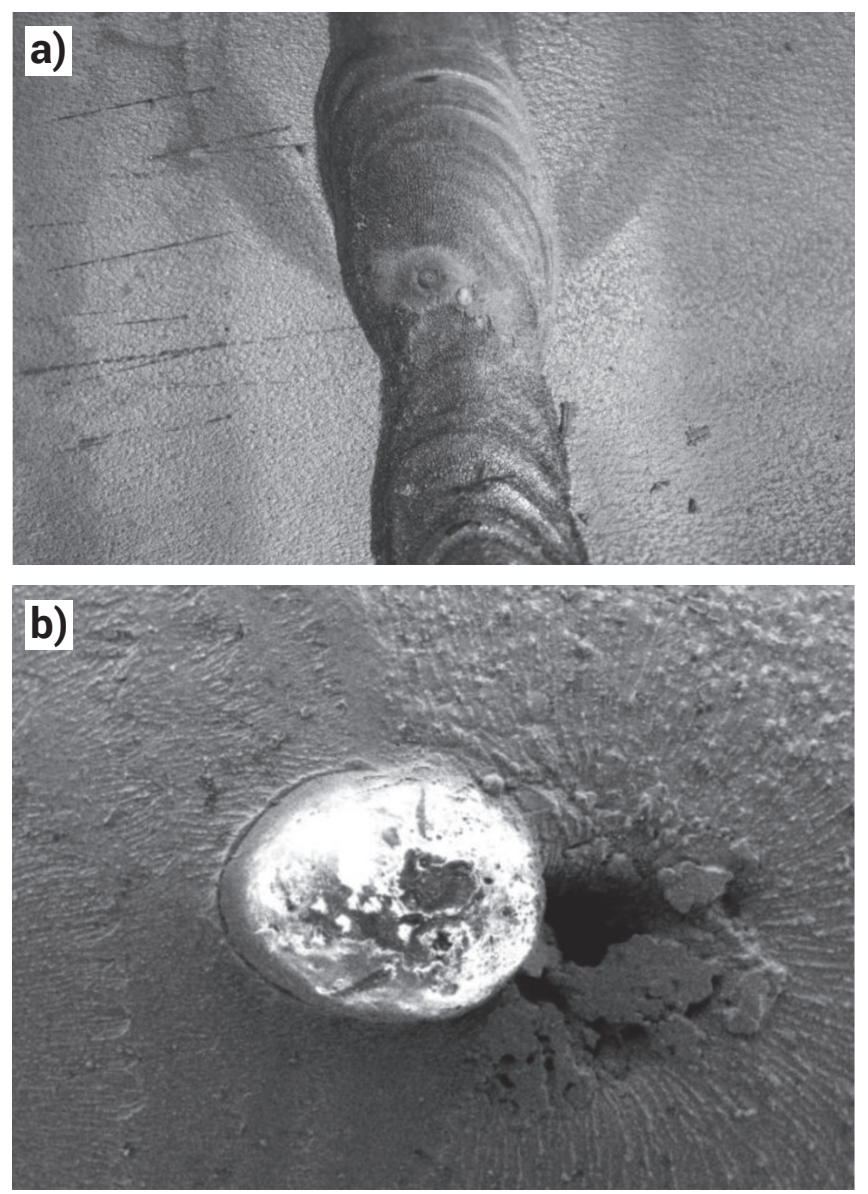

Rys. 4. a) Powierzchnia wewnętrzna rury ze spoiną i wtrąceniem żużla z ogniskiem korozyjnym, LM, pow. $6 x$, b) SEM pow. 50x

Fig. 4. a) Inner surface of the pipeline with weld root and slag inclusion which initiates pitting corrosion, LM, magnification 6x, b) SEM magnification $50 x$

Badania przeprowadzone na skaningowym mikroskopie elektronowym (SEM) ujawniły porowatości i kratery w otoczeniu wydzieleń żużli, rysunek 4b. Analiza EDS składu chemicznego wykazała, że wydzielenia zawierają głównie: tlen, węgiel, krzem, aluminium, wapń. Natomiast obszar wokół wydzieleń wykazuje podwyższoną zawartość chloru (powyżej 0,5\%). Świadczy to o kumulacji tego pierwiastka wokół wydzieleń, co w konsekwencji przyczynia się do inicjacji i dalszej propagacji korozji wżerowej w tym obszarze.

\section{Przypadek 2}

Kolejny przypadek uszkodzeń korozyjnych obserwowano na instalacji wody pitnej wykonanej z rur o średnicy $\varnothing 48 \mathrm{~mm}$ i grubości ścianki $3 \mathrm{~mm}$. Perforacja rury wystąpiła na kolanie $90^{\circ}$ bezpośrednio za spoiną obwodową (rys. 5).

Badania metalograficzne makroskopowe powierzchni wewnętrznej wykazały brak przetopu. Spawanie metodą TIG (141) wykonano bez ukosowania krawędzi rur i z tego powodu nie uzyskano pełnego przetopu i nie ukształtowano grani spoiny. Spawanie prawdopodobnie odbyło się bez użycia gazu formującego. W miejscu łączenia rur od strony wewnętrznej rury pozostała szczelina niemal na całym obwodzie rury (rys. 6).

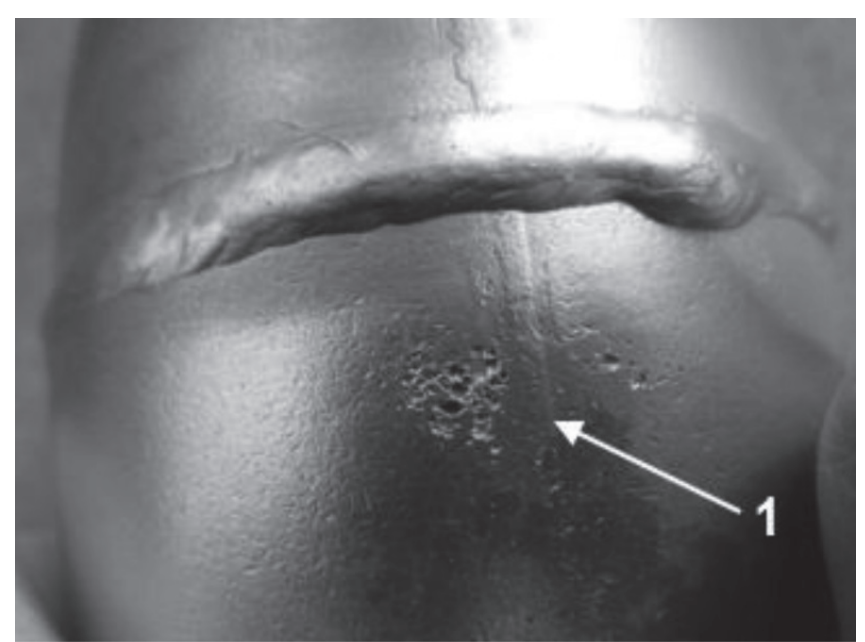

Rys. 5. Powierzchnia zewnętrzna kolana - perforacja ściany rury za spoiną (1)

Fig. 5. Knee pipe outer surface- perforation of pipeline wall behind face of the weld (1)

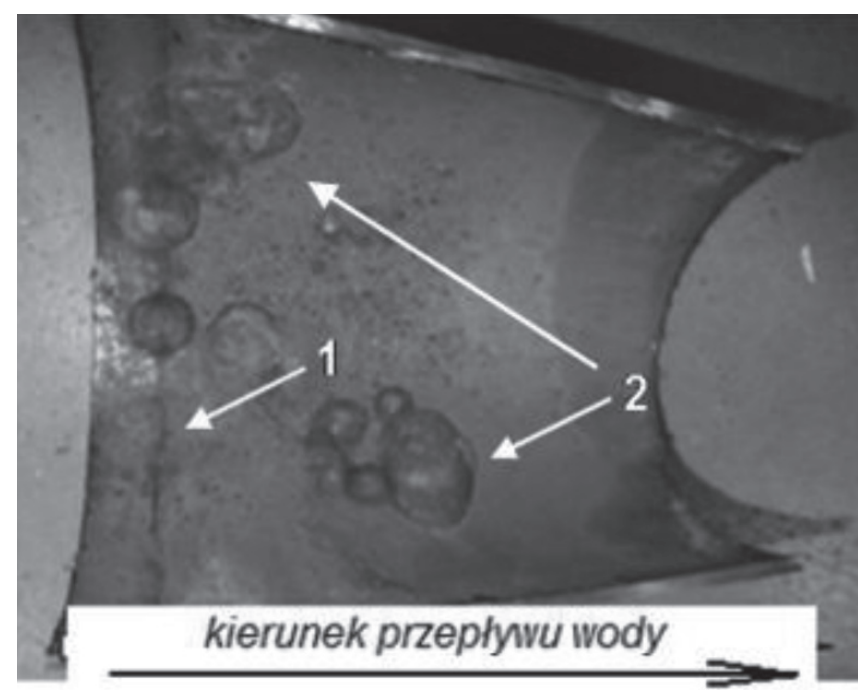

Rys. 6. Powierzchnia wewnętrzna uszkodzonego fragmentu rurociągu z widoczną szczeliną (1) i ogniskami korozji (2)

Fig. 6. Inner surface of damaged part of pipeline with the crevice (1) and corrosion initiation places (2)

Ogniska korozyjne umiejscowione były przeważnie za szczeliną w stosunku do kierunku przepływu wody. W miejscach tych występowały głębokie wżery powodujące niekiedy całkowitą perforację ściany rury.

W ogniskach korozyjnych skupione osady przyjmowały barwę czerwono-brunatną, a w kilku miejscach barwę zieloną, natomiast cała powierzchnia wewnętrzna rury była pokryta niezbyt grubymi osadami barwy żółtej, rysunek 7. Osady o zróżnicowanym zabarwieniu poddano mikroanalizie składu chemicznego. Uzyskane spektra przedstawione na rysunku 8.

Wszystkie osady zawierały pierwiastki pochodzące od naturalnych składników wody - węglanów wapnia i magnezu. Ponadto w osadach występowała znaczna ilość żelaza, stąd charakterystyczna czerwono-brunatna barwa osadów. Osady te najprawdopodobniej zostały przeniesione ze środowiska innej instalacji, połączonej z badaną. Na przeniesienie wskazuje też znaczny udział miedzi w osadzie barwy zielonkawej pokazanego na rysunku 7 i na spektrum na rysunku 8b. Udział chlorków, które wykryto w badanych osadach jest istotny dla trwałości warstw pasywnych stali austenitycznych. Wokół osadzonych cząstek następuje miejscowy wzrost stężenia chlorków, uszkodzenie warstewek pasywnych i inicjowanie wżerów korozyjnych. 


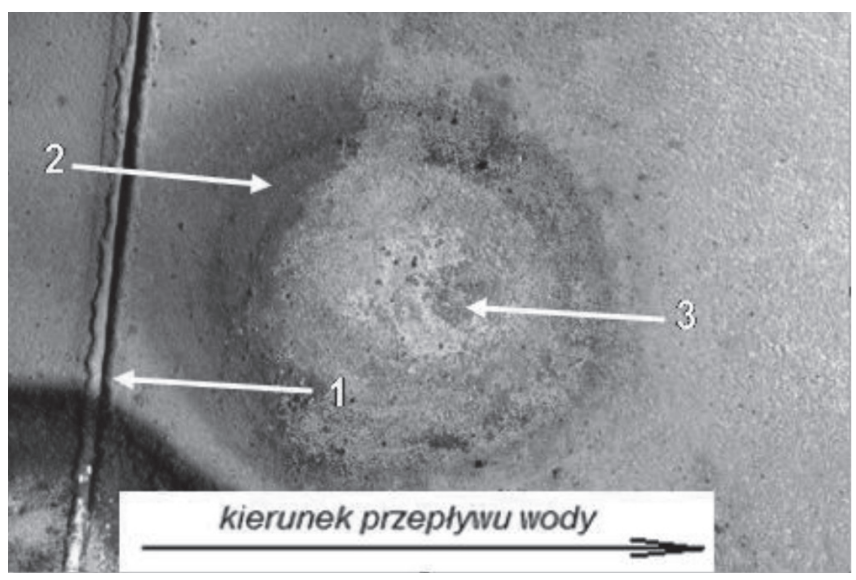

Rys. 7. Ognisko korozji wżerowej zlokalizowane za szczeliną (1), obszar o barwie rdzawo-brunatnej (2), obszar o barwie zielonkawej (3) Fig. 7. Pitting corrosion localized behind the crevice (1), reddishbrown colour area (2), greenish colour area (3)
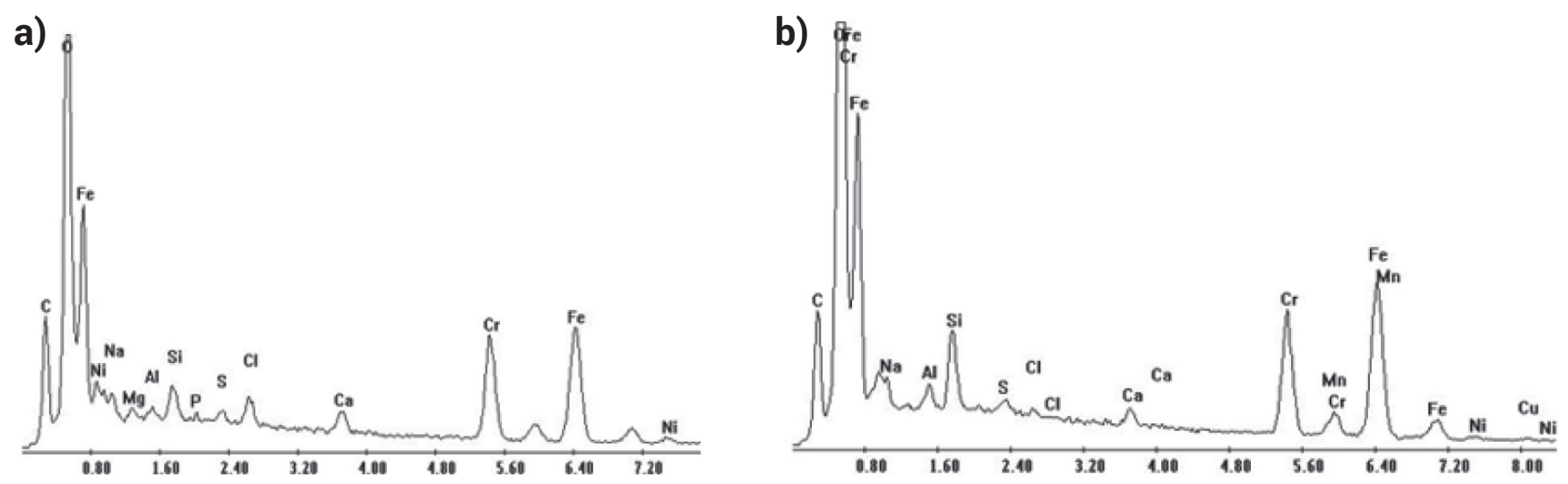

Rys. 8. a) widmo z warstwy ciemno-brunatnego osadu przedstawionego na rys. 7 i oznaczonego strzałką jako 2 , b) widmo z warstwy osadu o barwie zielonej przedstawionego na rys. 7 i oznaczonego strzałką jako 3

Fig. 8. a) EDS spectrum of reddish-brown area showed in the fig. 7 . and signed by the arrow as 2 , b) EDS spectrum of greenish colour area showed in the fig. 7. and signed by the arrow as 3

Tablica I. Skład chemiczny, równoważnik węgla CE oraz właściwości mechaniczne stali S460M Table I. Chemical composition, carbon equivalent CE and mechanical properties of S460M steel

\begin{tabular}{|c|c|c|c|c|c|c|c|c|c|c|c|}
\hline \multirow{2}{*}{ Badany obszar } & \multicolumn{11}{|c|}{$\%$ masy } \\
\hline & Si & Mn & $\mathbf{P}$ & S & $\mathrm{Cr}$ & $\mathrm{Ni}$ & 0 & $\mathrm{Fe}$ & $\mathrm{Cu}$ & $\mathrm{Ca}$ & $\mathrm{Cl}$ \\
\hline obszar o barwie rdzawo-brunatnej (2) & 1,3 & 1,2 & 0,4 & 0,7 & 17,3 & 4,2 & 16,2 & 55,9 & - & 1,4 & 1,4 \\
\hline obszar o barwie zielonkawej (3) & 2 & 1,8 & - & 0,5 & - & 2,5 & 19,5 & 69,3 & 3,4 & 0,8 & 0,2 \\
\hline
\end{tabular}

\section{Wnioski}

Doniesienia na temat licznych uszkodzeń instalacji wodociągowych wykonanych ze stali nierdzewnych austenitycznych oraz przeprowadzone analizy metalograficzne świadczą o niezwracaniu uwagi na czynniki warunkujące trwałość instalacji ze stali odpornych na korozję. Na podstawie przedstawionych przypadków uszkodzeń rurociągów z rur austenitycznych można sformułować następujące zalecenia:

- Obniżenie ryzyka korozji wżerowej stali austenitycznej w wodzie pitnej jest możliwe przez zastąpienie stali Cr-Ni typu AISI 304 stalą z dodatkiem $2 \div 4 \%$ Mo (AISI 316L) która może pracować przy wyższych stężeniach jonów chlorkowych w całym dopuszczalnym zakresie wymaganym dla wody przeznaczonej do picia.

- Należy przestrzegać właściwych technologii spawania rurociągów; konieczne jest stosowanie gazu formującego. Zaleca się stosowanie spawania orbitalnego TIG wykonywanego za pomocą zamkniętych głowic spawalniczych w atmosferze ochronnej argonu. Dzięki możliwości kształtowania grani, gładkości lica, spoiny nie wymagają żadnej obróbki mechanicznej, zapewniają powtarzalność jakości i minimalną liczbę niezgodności spawalniczych.

- W procesie wykonawczym instalacji, po zakończeniu spawania, koniecznym zabiegiem jest dokładne czyszczenie chemiczne rurociągu, przepłukiwanie wodą oraz pasywacja powierzchni.

- Należy ograniczać możliwości przenoszenia stałych cząstek i produktów korozji przez wodę w instalacji wodociągowej stosując skuteczne filtrowanie. 


\section{Literatura}

[1] A. Górecki: Trwałość instalacji - materiały metalowe instalacji wodnych, INSTAL, nr 7-8, s. 60-63, 2008.

[2] PN-EN 12502 1-4:2006 Ochrona materiałów metalowych przed korozją. Wytyczne do oceny ryzyka wystąpienia korozji w systemach rozprowadzania i magazynowania wody. Część 4: Czynniki oddziaływujące na stale odporne na korozję w urządzeniach energetycznych.

[3] PN-EN 10312:2006 Rury ze szwem ze stali odpornej na korozję do transportu wody i innych płynów wodnych - Warunki techniczne dostawy.

[4] Dyrektywa Rady 98/83/WE z dnia 3 listopada 1998 r. w sprawie jakości wody przeznaczonej do spożycia przez ludzi.

[5] PN-EN 10088-2:2007 Stale odporne na korozję - Część 2: Warunki techniczne dostawy blach i taśm ze stali nierdzewnych ogólnego przeznaczenia.

[6] J. Łabanowski, M. Głowacka: Eksploatacyjne uszkodzenia stali austenitycznych", Przegląd Spawalnictwa, nr 12, s. 3-9, 2010.

[7] S. Pankaj, R. Himadri: Pitting corrosion failure of an AISI stainless steel pointer rod, Engineering Failure Analysis, vol. 44, s. 400-407, 2014.

[8] J. Łabanowski, M. Głowacka: Przebarwienia powierzchni złączy spawanych stali odpornych na korozję, Przegląd Spawalnictwa, nr 6, s. 3-6, 2008.
[9] G. Rogalski, J. Łabanowski, D. Fydrych, A. Świerczyńska: Wpływ obróbki cieplnej na właściwości spawanych austenitycznych rur wymienników ciepła, Przegląd Spawalnictwa, nr 6, s. 24-31, 2014.

[10] A. Świerczyńska, G. Rogalski, D. Fydrych: Badania struktury i właściwości spawanych austenitycznych rur wymienników ciepła, Przegląd Spawalnictwa, nr 6, s. 11-16, 2010.

[11] T. von Moltke, P. C. Pistorius, R. F. Sandenbergh: The influence of heat-tinted surface layers on the corrosion resistance of stainless steels, INFACON 6, Proceedings of the 1 st International Chromium Steel and Alloys Congress, Cape Town, vol. 2, Johannesburg, SAIMM, s. 185-195, 1992.

[12] K. Kimbrel: Determinig acceptable levels of weld discolouration on mechanically polished and elecropolished stainless steel surfaces, Pharamaceutical Engineering, vol. 31, no. 6, 2011.

[13] S. Trigwell, G. Selvaduray: Effects of welding on the passive oxide film of electropolished 316L stainless steel, Journal of Material's Processing Technology, vol. 166, s. 30-43, 2005

[14] D. Kuta: Obróbka plastyczna stali kwasoodpornej w Instalcompact, INSTAL, nr 10, s. 41-42, 2013.

[15] A. Górecki: Stale odporne na korozję jako materiał instalacji wodnych, INSTAL, nr 7-8, s. 56-57, 2002. 